\title{
'Concepts and Rituals' Kirkpinar Oily Wrestling Festival as Unesco Unsute Cultural Heritage
}

\author{
Sengul D*
}

Department of Sports Science, Trakya University, TURKEY

ISSN: 2577-1914

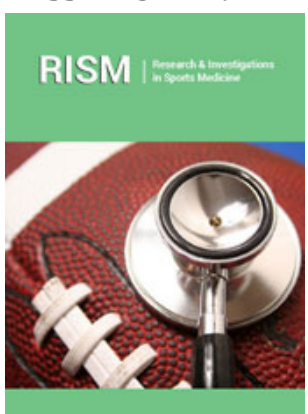

*Corresponding author: Sengul D,Sports Science Faculty, Trakya University, TURKEY

Submission: 洫September 21, 2020

Published: 㭗October 15, 2020

Volume 7 - Issue 2

How to cite this article: Sengul D. Opinions on Overweight Management. 'Concepts and Rituals' Kirkpinar Oily Wrestling Festival as Unesco Unsute Cultural Heritage. Res Inves Sports Med, 7(2), RISM.000657. 2020 DOI: $10.31031 /$ RISM.2020.07.000657

Copyright@ Sengul D, This article is distributed under the terms of the Creative Commons Attribution 4.0 International License, which permits unrestricted use and redistribution provided that the original author and source are credited.

\begin{abstract}
The purpose of this study; Kirkpinar, which has been listed as a UNESCO intangible cultural heritage, is to create international awareness by informing about the concepts and rituals of the oil wrestling festival. For this purpose, related resources have been scanned and examined. For this purpose, related resources have been scanned and examined. As a result, attracting the attention of young people around the world against the 'Kirkpinar Oil Wrestling Festival', which has been listed as a UNESCO intangible cultural heritage.
\end{abstract}

Keywords: UNESCO; Culture; Sports; Wrestling; Ritüel; Edirne

\section{Introduction}

If a sport contains traditional elements and national values, we can define it as traditional sports if it has been able to carry these elements from past to present. For this reason, it has its own unique cultural elements with its concepts such as oil wrestling, jazz, prayer, oil, salutation, pre-service, music, dome, agha institution, Kirkpinar tradition [1].

One of these is the "Kirkpinar Oil Wrestling Festival", which was recorded in 2010 on the representation list of UNESCO Intangible Cultural Heritage of Humanity. The acceptance of oil wrestling as a unique cultural heritage value of the world and sharing it as a common heritage of humanity will contribute greatly to the promotion and promotion of this culture [2]. Kirkpinar Oil Wrestling is a cultural event with its elements, rituals and cultural identity. The week of wrestling, which is visited by many local and foreign people, is stated as 'Kirkpinar Week'. While wrestling competitions are held in the last three days of this week, cultural events are held in the other time period (Küçükaltan et al, 2005). Wrestling is basically a physical and mental education that Turks do to prepare for war. This physical and mental education has been kept alive as a Turkish tradition until today. Kirkpinar wrestling has also been a part of this tradition. The most important cultural feature of Kirkpinar Oil Wrestling is that wrestlers show their strength and demonstrate their mastery. The name of this mastery is "Wrestling $[3,4]$.

\section{An Overview of Kirkpinar Oil Wrestling Concepts}

1) The name of kirkpinar oil wrestling: It is described as the gushing of forty springs from the place where the wrestlers named Ali and Selim from the forty brave commanded by Orhan Bey's son Süleyman Pasha were martyred and buried. It is known as "Rumeli Wrestling" among the people. Kirkpinar is defined as a form of wrestling based on competition, which includes oil wrestling, religious, national rituals and Turkish customs, traditions, and examples of charity and hospitality [5-8].

2) Elements of kirkpinar oil wrestling: In Kirkpinar Oil Wrestling, Golden Belt, Kispet, Red Dip Candle, Zembil and reward concepts are included.

3) Golden belt: It was prepared for the first time by Edirne Municipality in 1969 as the biggest award of wrestling and was put into practice. There are moon and star motifs on the right and left of the reliefs of Kurtdereli Mehmet Pehlivan and Adali Halil Pehlivan in the middle of the Golden Belt. The 'golden belt' 22 ounces given to the athlete who won the three times in a row at Kirkpinar [9] (Figures 1-4). 


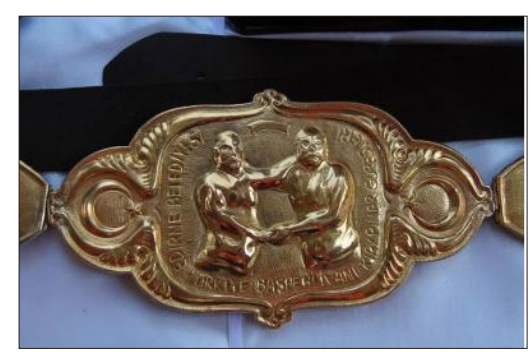

Figure 1: Altın kemer.

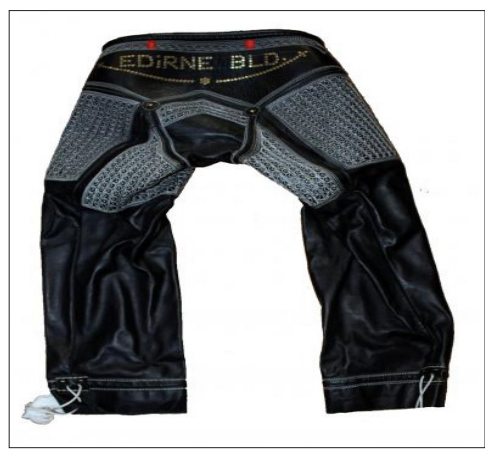

Figure 2: Kıspet.

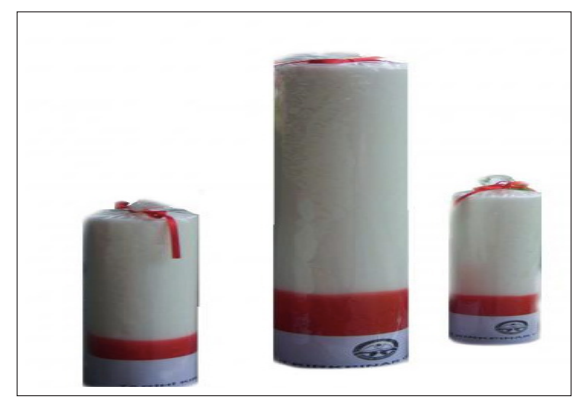

Figure 3: Kırmızı dipli mum.

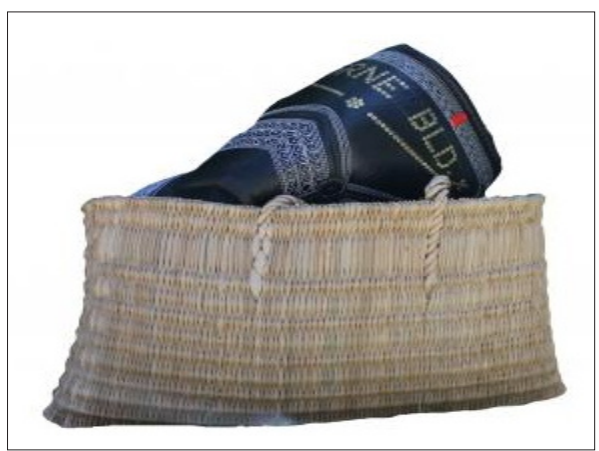

Figure 4: Zembil.

4) Kispet: Kispet comes from the Arabic word "kisve" and "kisvet". Covering the part of the body from the waist down to the top of the calf, the button is a garment sewn from the skin, without a band, without buttonhole (Kahraman, 1989: 94). Consisting of traditional handicrafts, it consists of the parts of the short, hoop, hopper, back, groove, trotter, waterfall and mirror [10].
5) Red bottom candle: The invitation symbol of Kirkpinar is a red bottom candle. In times when mass media were not common, the red-bottomed candle was sent to the towns and villages, wrestlers and well-known people by March, and they were invited to Kirkpinar. The phrase "calling with a red bottom candle", which is used frequently among the people, comes from here. It is one of the sine qua non of Kirkpinar. Today it is used as a symbol. City shopkeepers are also invited to Kirkpinar Oil Wrestling with a red bottom candle, accompanied by drum and zurna [11].

6) Zembil: In the wrestling thermology, he says "the bag that is used to carry the wedge of the wrestlers from aquatic plants such as kandira or reeds". It is a Persian word. Zembil is a bag-shaped traditional hand-made product made by hand on a special loom made of straw [12].

7) Awards: Prize money given by Edirne Municipality. The amount of the award is determined according to the competition categories.

\section{Rituals of Kirkpinar Oil Wrestling}

As a ritual word, it means "doing something, religious ceremony and rules". Ritual is defined as all kinds of traditional and formal practices created by those who have a belief by putting symbolic meaning into an alliance [5,13-15].

1) Peşrev: One of the Most Important Ritual Among These Elements is "Peşrev Pulling". Peşrev, in wrestling terminology, "Wrestlers are culture physics and warming movements for the purpose of caressing the audience and raising their spirituality just before starting wrestling [16]. Wrestlers (wrestlers) go three steps back, three steps forward, kneel on their right knees, touch their right hand to the ground, take them three times to the knee, their lips and head, and walk around the wrestling area, hug each other and hug and shake hands. When they meet again for the second time, they hold their opponents' pulley with their left hands, and they touch their opponent's right leg with their right hand and take their hands first to their lips and then to their heads. Then this movement is done in reverse. When the Wrestlers meet for the third time, they shake their arms left and right, holding each other on the back of their necks and on the right hands. When the wrestlers meet for the fourth time, they come face to face and roll each other's backs. After this movement, the wrestlers who shake each other's hands for a while, finally shake hands and wish each other success when they face each other, and their hands roll each other's back and start wrestling at each other's neck [17].

2) Oiling: The wrestlers gather around the oil boilers placed in the square (competition area) and lubricate each other. Oiling has a ritual. First, oil is applied to the left shoulder, chest, left arm and cuff. Afterwards, oil is applied to the right shoulder, chest, right arm and cuff with left hand. Then the wrestlers grease each other's back. If he needs to be lubricated during wrestling, he will take the permission of the referee and his opponent and eliminate the need for oiling (Figures 5-7). 


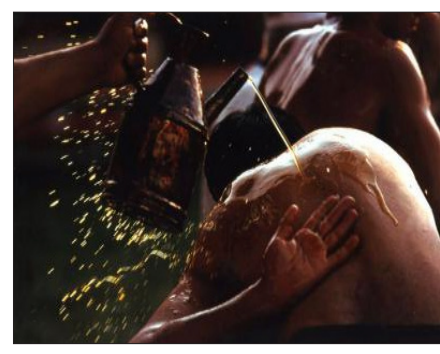

Figure 5: Oiling.

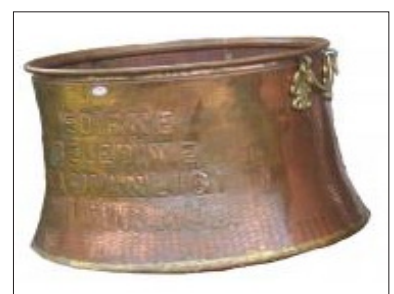

Figure 6: Oil boiler.

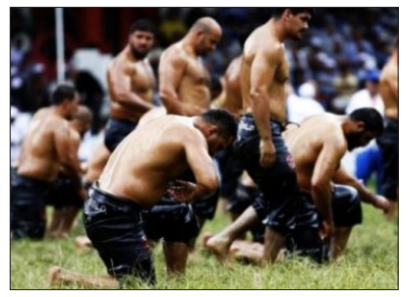

Figure 7: Peşrev.

3) Oil boiler: Oil boilers are placed next to the dressing rooms and all wrestlers, including competing wrestlers, are poured oil on each other's back.

4) Prayer: As a living carrier of verbal cultural heritage, jazzlists provide a warm dialogue between people from different cultures with their literary poetic presentations called "prayer". Prayer, which is one of the important rituals of Kirkpinar Oil Wrestling, is the lyrics of the words that Cazgir spoke in verse, before he released the wrestlers to wrestle. Jazzers continue this tradition from past to present.

5) Wrestling games: Elese, scythe, kund, violin wrapping, pile, yoke, cross, shackle, plunge ... etc. are just a few of the techniques applied to outperform your opponent in competitions [18]

Kirkpinar Marși: Kirkpinar Anthem; The anthem, whose lyrics and music belongs to Beyazit Sans, was accepted as an official anthem in 2002. Kirkpinar Oil Wrestling is a factor that shows how creative it is in the intangible cultural heritage with its unique melodies and verbal acts. Kirkpinar oil wrestling; It is an important cultural heritage both with its relationship with Hidirellez cult and its religious rituals. Due to these features oil wrestling in Turkey's attended for the first time in 2008. "Europeans distinguished Destinations Award-winning and 16 November 2010 at the UNESCO representative list of Humanity's Intangible Cultural Heritage 'has been included $[19,20]$. Kirkpinar greased wrestling, as well as its religious, social and moral dimensions, appears as a symbol of Turkish and Islamic culture with its sporty aspect and competition form. Since the past, Kirkpinar wrestling festival has a mission that represents the personality, social-cultural accumulation and selfworth of Turkish people. With this aspect, it has been an important part of world culture and civilization history. UNESCO's historical Kirkpinar wrestling festival included in the list of cultural heritage to be protected. It is thought that the cultural industry, which will make the historical Kirkpinar festival universal, ensure the preservation of cultural values in the traditional way, and will develop in the city will contribute to ensuring sustainable development and reaching international audiences [21-29].

\section{References}

1. Ylldiran İ (2000) Evaluation of the differences of traditıonal oil wrestling with cultural, structural and scientific perspective of modern mattress wrestlıng. Gazı Journal of Physical Education and Sports Sciences 5(1): 53-62.

2. Özdemır G, Çalışkan V (2018) A tradıtıonal sports geography: oll wrestlıng in turkey (Edırne Kırkpınar-And-Canakkale Wrestlıng Pavilıons). TÜCAUM 30: 3-6.

3. Güven Ö (1999) Sports culture in turks, Ataturk Cultural Center Presidency Publicatıons, Ankara, Turkey.

4. Gökkaya ÖK (2014) In: Kıspet (Ed.), Fatıh Genel, Zeytın Publıshıng Group, Çanakkale, Turkey.

5. Küçük MA, Sılık CE (2018) From hıdırellez cult to a relıgıous rıtual: "kırkpınar oll wrestlıng. IntJCSS. 4: e-ISSN: 2458-9381I.

6. Atabeyoğlu C (1985) Reforms of the republıc sports" reforms of the republic of turkey encyclopedia, C.6, Communication Publications, Istanbul, Turkey, p. 1474-1489.

7. Erdem H (2009) From bırth to present, Kırkpınar Wrestlıng, Ceren Publıshıng, Edırne, Turkey.

8. Dervışoğlu M (2012) Analysıs of kırkpınar wrestlıng in folklore, Unpublıshed Master's Thesıs, Edırne, Turkey.

9. http://www.edirnekirkpinar.com/tr/yazi/1-ogeler/1-altin-kemer

10. http://www.edirnekirkpinar.com/tr/yazi/1-ogeler/3-kispet

11. http://www.edirnekirkpinar.com/tr/yazi/1-ogeler/5-kirmizi-diplimum

12. http://www.edirnekirkpinar.com/tr/yazi/1-ogeler/4-zembil

13. Hançerlığlu 0 (2000) World belıefs dictıonarÿ, Remzı Bookstore, Istanbul, Turkey.

14. Bell C (2009) Ritual theory, Ritual Practıce, Oxford University Press, Oxford, UK.

15. Haunerland W (2013) "Ritual", islam-christian concepts dictionary, Ankara, Turkey, C.2, pp. 633-634

16. Temızoğlu K (note) Ata sporu oll wrestlıng and kırkpınar, Istanbul, Mehmet Tunagür Publıshıng House, (Publısh Date Not Specıfied).

17. Gül O, Gül M, Soygüden A (2019) Tradıtıonal oll wrestlıng and "peshrev pullıng" rituals.

18. http://www.edirnekirkpinar.com/tr/yazi/2-ritueller/12-guresoyunlari

19. Baykara T (2001) Vıews on turkısh cultural history, Atatürk Hıgher Instıtutıon Atatürk Culture Center Publıcatıon, Ankara, Turkey, p. 252.

20. Tunca A (2016) Wrestlıng of edırnelı islander halıl pehlıvan and wrestlıng-oll wrestlıng -kırpınar, Munıcıpality Publicatıons, Edırne, Turkey, p: 21. 
21. Erdem H (2007) History of kırkpınar wrestlıng, II. Historıcal Kırkpınar Symposıum Papers, Trakya Unıversity Publıcatıon, Edırne, Turkey p. 74, ISBN: 978-975-374-074-6, P.145-149

22. Boyacıoğlu E (2005) Socı-economıc contributıon of kırkpınar oil wrestlıng to the edirne province, $1^{\text {st }}$ International Kırkpınar Symposıum, Edirne, Turkey.

23. https://www.researchgate.net/publication/331649250

24. http://www.edirnekirkpinar.com/tr/yazi/2-ritueller/11-pesrev
25. http://www.edirnekirkpinar.com/tr/yazi/2-ritueller/10-yaglanma

26. http://www.edirnekirkpinar.com/tr/yazi/2-ritueller/9-salavatlamadualama

27. http://www.edirnekirkpinar.com/tr/yazi/2-ritueller/14-kirkpinarmarsi

28. Http.www.Unesco.Org

29. https://pehlivanblog.wordpress.com/tag/pesrev/

For possible submissions Click below: 